\title{
Nitrogen:Phosphorus:Potassium Ratios Affect Production of Two Herbaceous Perennials
}

\author{
H.T. Kraus ${ }^{1,4}$ \\ Department of Horticultural Science, North Carolina State University, Kilgore \\ Hall Box 7609, Raleigh, NC 27695-7609
}

\author{
S.L. Warren ${ }^{2}$ \\ Department of Horticulture, Forestry, and Recreation Resources, 2021 \\ Throckmorton Plant Sciences Center, Kansas State University, Manhattan, \\ KS 66506
}

\section{G.J. Bjorkquist ${ }^{3}$, A.W. Lowder ${ }^{3}$, C.M. Tchir ${ }^{3}$, and K.N. Walton ${ }^{3}$ Department of Horticultural Science, North Carolina State University, Kilgore Hall Box 7609, Raleigh, NC 27695-7609}

Additional index words. mineral nutrient concentration, fertilization, mineral nutrition, Rudbeckia fulgida var. sullivantii Ait. 'Goldsturm' (rudbeckia) and Hibiscus moscheutos L. (hibiscus)

Abstract. A series of experiments were undertaken to determine the effects of nitrogen $(\mathrm{N})$, phosphorus $(\mathrm{P})$, and potassium $(\mathrm{K})$ concentrations and $\mathrm{N}: \mathrm{P}: \mathrm{K}$ ratio on flowering and vegetative growth of two herbaceous perennials, Hibiscus moscheutos L. (hibiscus) and Rudbeckia fulgida var. sullivantii Ait. 'Goldsturm' (rudbeckia). Plant growth and flowering of both hibiscus and rudbeckia were influenced by concentration and ratio of $N$, $P$, and $K$. When $N$ was held constant at $100 \mathrm{mg} \cdot \mathrm{L}^{-1}, 4: 1 \mathrm{~N}: \mathrm{K}\left(25 \mathrm{mg} \cdot \mathrm{L}^{-1} \mathrm{~K}\right)$ and 16:1 $\mathrm{N}: \mathrm{P}\left(6.3 \mathrm{mg} \cdot \mathrm{L}^{-1} \mathrm{P}\right)$ were optimal for growing hibiscus, whereas higher $\mathrm{K}$ concentration (1:2 N:K, $\left.200 \mathrm{mg} \cdot \mathrm{L}^{-1} \mathrm{~K}\right)$ and lower $P$ concentration $\left(32: 1 \mathrm{~N}: \mathrm{P}, 3.1 \mathrm{mg} \cdot \mathrm{L}^{-1} \mathrm{~N}\right)$ were required for optimal growth of rudbeckia. However, when holding $N$ constant at 100 mg. $L^{-1}$ and varying both $P$ and $K$ in the fertilizer solutions, higher $P$ and $K$ concentrations and a 2:1:2 (50 $\left.\mathrm{mg} \cdot \mathrm{L}^{-1} \mathrm{P}, 100 \mathrm{mg} \cdot \mathrm{L}^{-1} \mathrm{~K}\right) \mathrm{N}: \mathrm{P}: \mathrm{K}$ ratio best supported hibiscus growth, whereas 3:1:2 (33 $\left.\mathrm{mg} \cdot \mathrm{L}^{-1} \mathrm{P}, 66 \mathrm{mg} \cdot \mathrm{L}^{-1} \mathrm{~K}\right) \mathrm{N}: \mathrm{P}: \mathrm{K}$ was needed for growth of rudbeckia. Finally, when both $N$ concentration and $N: P: K$ ratio were altered, optimum growth of both hibiscus and rudbeckia was achieved at similar and lower $\mathbf{P}$ and $\mathrm{K}$ concentrations (25 $\mathrm{mg} \cdot \mathrm{L}^{-1} \mathrm{P}$ and $50 \mathrm{mg} \cdot \mathrm{L}^{-1} \mathrm{~K}$ ) and $200 \mathrm{mg} \cdot \mathrm{L}^{-1} \mathrm{~N}$. An 8:1:2 N:P:K ratio was optimum for production of both hibiscus and rudbeckia, although 12:1:2 N:P:K (200 $\left.\mathrm{mg} \cdot \mathrm{L}^{-1} \mathrm{~N}, 17 \mathrm{mg} \cdot \mathrm{L}^{-1} \mathrm{P}, 33 \mathrm{mg} \cdot \mathrm{L}^{-1} \mathrm{~K}\right)$ produced similar growth of rudbeckia. Based on results of these two herbaceous perennials, it appears herbaceous perennials have $\mathrm{N}$ requirements similar to annual plants and $P$ and $K$ requirements similar to woody plants. Furthermore, the two herbaceous perennials used in this study required nutrients in the fertilizer solution at a higher N:P:K ratio than either annual or woody plants. Foliar concentrations of $2.2 \% \mathrm{~N}, 0.4 \% \mathrm{P}$, and $1.9 \% \mathrm{~K}$ were adequate for growth of hibiscus, whereas $2.4 \% \mathrm{~N}, 0.2 \% \mathrm{P}$, and $2.6 \% \mathrm{~K}$ were required to maximize growth of rudbeckia.

Although successful container-grown plant production requires management of many variables, nutrient management is critical, requiring appropriate selection and use of fertilizers

\footnotetext{
Received for publication 24 Nov. 2010. Accepted for publication 11 Mar. 2011.

This research was funded in part by the North Carolina Agricultural Research Service (NCARS), Raleigh, NC, and by grants from the Perennial Plant Association, Hilliard, OH.

Appreciation is extended to William M. Reece, Jeanne Newell, and Shauna Dorman for technical assistance. Use of trade names in this publication does not imply endorsement by the NCARS of products named nor criticism of similar ones not mentioned.

${ }^{1}$ Assistant Professor.

${ }^{2}$ Professor and Head.

${ }^{3}$ Undergraduate Research Assistants.

${ }^{4}$ To whom reprint requests should be addressed; e-mail Helen_Kraus@ncsu.edu.
}

to optimize plant growth and limit waste and cost of fertilizer. Mineral nutrient recommendations for woody, perennial plant production include daily applications of 50 to $100 \mathrm{mg} \cdot \mathrm{L}^{-1}$ $\mathrm{N}, 10$ to $20 \mathrm{mg} \cdot \mathrm{L}^{-1} \mathrm{P}$, and 25 to $50 \mathrm{mg} \cdot \mathrm{L}^{-1} \mathrm{~K}$ in a $5: 1: 3 \mathrm{~N}: \mathrm{P}: \mathrm{K}$ ratio (Wright and Niemiera, 1987). Schnelle and White (2004) provided similar recommendations for $\mathrm{P}\left(5\right.$ to $\left.15 \mathrm{mg} \cdot \mathrm{L}^{-1}\right)$ and $\mathrm{K}$ ( 25 to $75 \mathrm{mg} \cdot \mathrm{L}^{-1}$ ) but with substantially higher $\mathrm{N}$ concentrations of 100 to 200 $\mathrm{mg} \cdot \mathrm{L}^{-1}$ in a traditional ratio of $3: 1: 2$. In contrast, $\mathrm{N}$ recommendations for annual, herbaceous plant production are generally higher ranging from 90 to $255 \mathrm{mg} \cdot \mathrm{L}^{-1} \mathrm{~N}$ applied daily with a $2: 1: 2 \mathrm{~N}: \mathrm{P}: \mathrm{K}$ ratio (Bailey and Nelson, undated). Although many herbaceous perennials have the same accelerated growth rate as annual plants, they also store nutrients in roots for regrowth after a dormant season like a woody plant. Thus, herbaceous perennials may have different requirements for concentration and ratio of nutrients than either woody, perennial or herbaceous, annual plants.

Research to date has provided few recommendations for appropriate concentrations and ratios of nutrients for container production of herbaceous perennials. Adam and Sluzis (2005) suggest $136 \mathrm{mg} \cdot \mathrm{L}^{-1} \mathrm{~N}$ applied every other day for production of a wide range of container-grown shade and sun-tolerant herbaceous perennials, whereas Hipp et al. (1989) recommended $166 \mathrm{mg} \cdot \mathrm{L}^{-1} \mathrm{~N}$ applied weekly for Melampodium leucanthum Ton \& Gray (blackfoot daisy). Additionally, little information is available regarding appropriate concentrations of $\mathrm{P}$ and $\mathrm{K}$, and even fewer studies have examined $\mathrm{N}: \mathrm{P}: \mathrm{K}$ ratio for production of herbaceous perennials. Maximum growth of Melampodium leucanthum, Salvia greggii Gray (autumn sage), and Scaevola aemula R. Br. 'New Wonder' (fanflower) was achieved with $\mathrm{P}$ concentrations of 30,50 , and 14.5 $\mathrm{mg} \cdot \mathrm{L}^{-1}$, respectively, and $\mathrm{N}: \mathrm{P}$ ratios of $5.5: 1$, $4: 1$, and 14:1, respectively (Hipp et al., 1988, 1989; Zhang et al., 2004), whereas growth of Hakonechloa macra Makino 'Aureola' (Hakone grass) was maximized with 48 $\mathrm{mg} \cdot \mathrm{L}^{-1} \mathrm{P}$ and a $\mathrm{N}: \mathrm{P}$ ratio of $10: 1$ to $20: 1$ (Harvey et al., 2004). Complicating the nutrient concentration recommendations for herbaceous perennials is the tendency for luxury consumption of nutrients. Both Adam and Sluzis (2005) and Scoggins (2005) reported more than 20 different species of herbaceous perennials absorbed more nutrients than were required to maintain maximum growth. Furthermore, these authors indicated higher-quality plants were often produced with lower concentrations of nutrients. Although the ratio of $\mathrm{N}: \mathrm{P}: \mathrm{K}$ can affect flowering and growth (Higaki et al., 1992; Melton and Dufault, 1991), it also affects the cost of fertilizer manufacturing. Fertilizer manufacturers make decisions on the application concentration and ratio of nutrients based on targeted cost for the grower, environmental conditions during production, and the nutrient needs of the plant.

More definitive recommendations are needed for the concentrations and ratio of $\mathrm{N}, \mathrm{P}$, and $\mathrm{K}$ for container production of herbaceous perennials. Thus, four experiments were conducted during 2005-2007 to determine the effects of $\mathrm{N}, \mathrm{P}$, and $\mathrm{K}$ concentration and $\mathrm{N}: \mathrm{P}: \mathrm{K}$ ratio on flowering and vegetative growth of two herbaceous perennials.

\section{Materials and Methods}

Cultural practices and data management for all experiments. Seedlings of Rudbeckia fulgida var. sullivantii Ait. 'Goldsturm' (rudbeckia) and Hibiscus moscheutos L. (hibiscus) grown in $16.39-\mathrm{cm}^{3}$ containers were transferred into 3.8-L black plastic containers filled with an 8 aged pine bark:1 sand (by volume) substrate amended with $1.2 \mathrm{~kg} \cdot \mathrm{m}^{-3}$ dolomitic limestone [providing calcium $(\mathrm{Ca})$ and magnesium $(\mathrm{Mg})]$ in all experiments. The cultivar of hibiscus differed as a result of plant availability. 'Luna Blush' hibiscus, 'Luna White' hibiscus, and 'Luna Red' hibiscus were used in 2005, 2006, and 2007, respectively. Plants 
were grown in a greenhouse with $27 \pm 1.0 / 18$ ${ }^{\circ} \mathrm{C} \pm 1.0 \mathrm{~d} /$ night temperatures in Raleigh, $\mathrm{NC}$, between May and August with natural irradiance and photoperiod. Concentrated stock solutions were prepared for each treatment and the treatments were applied with a fertigation system using two Dosatron D16I proportional injectors (Dosatron, Inc., Clearwater, FL) connected in series. Reagent-grade ammonium nitrate, monoammonium phosphate, and potassium sulfate were used to supply $\mathrm{N}, \mathrm{P}$, and $\mathrm{K}$, respectively, using one Dosatron injector (Table 1). Micronutrients were supplied from a concentrated modified Hoagland's solution (Hoagland and Arnon, 1950) using boric acid, copper sulfate, manganese chloride, ammonium molybdate, zinc sulfate, and chelated iron to supply the boron $(\mathrm{B})$, copper $(\mathrm{Cu})$, manganese (Mn), molybdenum (Mo), zinc ( $\mathrm{Zn})$, and iron $(\mathrm{Fe})$ at a constant concentration $(0.5,0.02$, $0.5,0.1,0.05$, and $5 \mathrm{mg} \cdot \mathrm{L}^{-1}$ for $\mathrm{B}, \mathrm{Cu}, \mathrm{Mn}, \mathrm{Mo}$, $\mathrm{Zn}$, and $\mathrm{Fe}$, respectively) through a second Dosatron injector. The injectors diluted the stock solutions with tap water having a $\mathrm{pH}$ of 7.4 and containing $\mathrm{NO}_{3}-\mathrm{N}, \mathrm{NH}_{4}-\mathrm{N}, \mathrm{P}, \mathrm{K}, \mathrm{Ca}$, $\mathrm{Mg}$, and alkalinity at $0.10,0.96,0.5,7.0,10.0$, 4.0, and $20.0 \mathrm{mg} \cdot \mathrm{L}^{-1}$, respectively. The $\mathrm{N}, \mathrm{P}$, and $\mathrm{K}$ treatments and micronutrient solution were delivered to each container through a single pressure-compensated spray stake (AccuStick; Wade Mfg. Co., Fresno, CA). Between each treatment the Dosatrons and appropriate irrigation lines were flushed with tap water, drained, and primed with the next treatment before application.

Leaching fractions $(\mathrm{LF}=$ volume leached $\div$ volume applied) were measured every 2 weeks, and irrigation volume was adjusted to maintain a 0.2 LF for each treatment. Additionally, substrate solution was collected to determine electrical conductivity (EC) and pH every 2 to 4 weeks depending on the experiment using the pour-through nutrient extraction method (Wright, 1986). EC and $\mathrm{pH}$ were determined through a combination $\mathrm{EC} / \mathrm{pH}$ meter (Accumet 50; Fisher Scientific Co., Pittsburgh, PA).

Flower buds were counted, removed, and dried to a constant weight at $62{ }^{\circ} \mathrm{C}$ when they began to open (show color). At harvest, plants were separated into flower buds, flowers, leaves, stems, and roots. Leaf area was measured using a LI-COR 3000 leaf area meter (LI-COR, Lincoln, NE). Roots were washed to remove substrate. Before drying, all leaves were triplerinsed in deionized water. All plant parts were dried to a constant weight at $62{ }^{\circ} \mathrm{C}$.

After drying, flower buds, flowers, leaves, stems, and roots were weighed and used to calculate top dry weight (leaf + stem dry weight), flower dry weight (flower + flower bud dry weight), and total dry weight (leaf + stem + root + flower + flower bud dry weight). After weighing, leaves were ground with a Foss Tecator Cyclotec ${ }^{\mathrm{TM}} 1093$ sample mill (Analytical Instruments, LLC, Golden Valley, MN) to pass a $0.5-\mathrm{mm}$ sieve or smaller. Foliar $\mathrm{N}$ concentration was determined by oxygen combustion gas chromatography with an elemental analyzer (NA 1500; CE Elantech Instruments, Lakewood, NJ.) (Campbell and Plank, 1992). Foliar P, K, Ca, Mg, sulfur (S), B, Cu, Fe, Mn, and $\mathrm{Zn}$ concentrations were determined with an inductively coupled plasma (ICP) spectrometer (Donohue and Aho, 1992) (Optima
3300 DV ICP Emission Spectrometer; Perkin Elmer Corp., Shelton, CT) following openvessel $\mathrm{HNO}_{3}$ digestion in a microwave digestion system (CEM Corp., Matthews, NC) (Campbell and Plank, 1992). Tissue samples were analyzed by the North Carolina Department of Agriculture and Consumer Services, Agronomic Division, Raleigh, NC.

All variables were subjected to analysis of variance (ANOVA) and regression analyses, where appropriate, using Proc ANOVA and Proc REG in SAS Version 9.01 (SAS Institute Inc., 2001) and were considered significant at $P \leq 0.05$. Species $\times$ treatment interactions were evaluated for all variables measured except foliar nutrient concentrations. If the species $\times$ treatment interaction was significant, data were reanalyzed by species, whereas when the interaction was nonsignificant, treatment main effects were discussed. Species $\times$ treatment interactions were not evaluated for foliar nutrient concentrations so recommendations could be provided for each species. Treatment mean comparisons between $\mathrm{N}$ concentrations and $\mathrm{N}: \mathrm{P}: \mathrm{K}$ ratios in the 2007 experiment were made by single $\mathrm{df}$ linear contrast tests (SAS Institute, Inc., 2001). Simple linear or polynomial curves were fitted to the data when significant trends were identified. The maximum of the polynomial curve was calculated as a first-order derivative of the independent variable where the dependent variable equaled zero.

Nitrogen:potassium ratio and nitrogen: phosphorus ratio experiments. During Summer 2005 , two concurrent but separate $2 \times 6$ factorial experiments were conducted in a randomized

Table 1. Nutrient solutions used in 2005, 2006, and 2007. ${ }^{\mathrm{z}}$

\begin{tabular}{|c|c|c|c|c|c|c|c|c|c|c|c|c|}
\hline \multirow{3}{*}{$\begin{array}{l}\text { Nutrient } \\
\text { source }\end{array}$} & $\mathrm{mg} \cdot \mathrm{L}^{-1}$ & $\mathrm{mM}$ & $\mathrm{mg} \cdot \mathrm{L}^{-1}$ & $\mathrm{mM}$ & $\mathrm{mg} \cdot \mathrm{L}^{-1}$ & $\mathrm{mM}$ & $\mathrm{mg} \cdot \mathrm{L}^{-1}$ & $\mathrm{~mm}$ & $\mathrm{mg} \cdot \mathrm{L}^{-1}$ & $\mathrm{mM}$ & $\mathrm{mg} \cdot \mathrm{L}^{-1}$ & $\mathrm{mM}$ \\
\hline & \multicolumn{12}{|c|}{2005} \\
\hline & \multicolumn{2}{|c|}{$1: 1 \mathrm{~N}: \mathrm{P}$} & \multicolumn{2}{|c|}{$2: 1 \mathrm{~N}: \mathrm{P}$} & \multicolumn{2}{|c|}{$4: 1 \mathrm{~N}: \mathrm{P}$} & \multicolumn{2}{|c|}{$8: 1 \mathrm{~N}: \mathrm{P}$} & \multicolumn{2}{|c|}{$16: 1 \mathrm{~N}: \mathrm{P}$} & \multicolumn{2}{|c|}{$32: 1 \mathrm{~N}: \mathrm{P}$} \\
\hline $\mathrm{NH}_{4} \mathrm{NO}_{3}$ & 100 & 7.1 & 100 & 7.1 & 100 & 7.1 & 100 & 7.1 & 100 & 7.1 & 100 & 7.1 \\
\hline $\mathrm{NH}_{4} \mathrm{H}_{2} \mathrm{PO}_{4}$ & 100 & 3.2 & 50 & 1.6 & 25 & 0.8 & 12.5 & 0.4 & 6.25 & 0.2 & 3.1 & 0.1 \\
\hline \multirow[t]{3}{*}{$\mathrm{K}_{2} \mathrm{SO}_{4}$} & 50 & 1.3 & 50 & 1.3 & 50 & 1.3 & 50 & 1.3 & 50 & 1.3 & 50 & 1.3 \\
\hline & \multicolumn{12}{|c|}{2005} \\
\hline & \multicolumn{2}{|c|}{$1: 1 \mathrm{~N}: \mathrm{K}$} & \multicolumn{2}{|c|}{$1: 2 \mathrm{~N}: \mathrm{K}$} & \multicolumn{2}{|c|}{$2: 1 \mathrm{~N}: \mathrm{K}$} & \multicolumn{2}{|c|}{$4: 1 \mathrm{~N}: \mathrm{K}$} & \multicolumn{2}{|c|}{$8: 1 \mathrm{~N}: \mathrm{K}$} & \multicolumn{2}{|c|}{$16: 1 \mathrm{~N}: \mathrm{K}$} \\
\hline $\mathrm{NH}_{4} \mathrm{NO}_{3}$ & 100 & 7.1 & 100 & 7.1 & 100 & 7.1 & 100 & 7.1 & 100 & 7.1 & 100 & 7.1 \\
\hline $\mathrm{NH}_{4} \mathrm{H}_{2} \mathrm{PO}_{4}$ & 25 & 0.8 & 25 & 0.8 & 25 & 0.8 & 25 & 0.8 & 25 & 0.8 & 25 & 0.8 \\
\hline \multirow[t]{3}{*}{$\mathrm{K}_{2} \mathrm{SO}_{4}$} & 200 & 5.1 & 100 & 2.6 & 50 & 1.3 & 25 & 0.6 & 12.5 & 0.3 & 6.25 & 0.2 \\
\hline & \multicolumn{12}{|c|}{2006} \\
\hline & \multicolumn{2}{|c|}{$2: 1: 2 \mathrm{~N}: \mathrm{P}: \mathrm{K}^{\mathrm{y}}$} & \multicolumn{2}{|c|}{$3: 1: 2 \mathrm{~N}: \mathrm{P}: \mathrm{K}$} & \multicolumn{2}{|c|}{$4: 1: 2 \mathrm{~N}: \mathrm{P}: \mathrm{K}$} & \multicolumn{2}{|c|}{$8: 1: 2 \mathrm{~N}: \mathrm{P}: \mathrm{K}$} & \multicolumn{2}{|c|}{ 12:1:2 N:P:K } & \multicolumn{2}{|c|}{ 24:1:2 N:P:K } \\
\hline$\overline{\mathrm{NH}_{4} \mathrm{NO}_{3}}$ & 100 & 5.5 & 100 & 6.1 & 100 & 6.3 & 100 & 6.7 & 100 & 6.9 & 100 & 7.0 \\
\hline $\mathrm{NH}_{4} \mathrm{H}_{2} \mathrm{PO}_{4}$ & 50 & 1.6 & 33 & 1.1 & 25 & 0.8 & 12.5 & 0.4 & 8 & 0.3 & 4 & 0.1 \\
\hline \multirow[t]{3}{*}{$\mathrm{K}_{2} \mathrm{SO}_{4}$} & 100 & 2.6 & 66 & 1.7 & 50 & 1.3 & 15 & 0.6 & 16 & 0.4 & 8 & 0.2 \\
\hline & \multicolumn{12}{|c|}{2007} \\
\hline & \multicolumn{2}{|c|}{$4: 1: 2 \mathrm{~N}: \mathrm{P}: \mathrm{K}$} & \multicolumn{2}{|c|}{$4: 1: 2 \mathrm{~N}: \mathrm{P}: \mathrm{K}$} & \multicolumn{2}{|c|}{$4: 1: 2 \mathrm{~N}: \mathrm{P}: \mathrm{K}$} & \multicolumn{2}{|c|}{$8: 1: 2 \mathrm{~N}: \mathrm{P}: \mathrm{K}$} & $8: 1: 2$ & & $8: 1: 2$ & \\
\hline $\mathrm{NH}_{4} \mathrm{NO}_{3}$ & 50 & 3.2 & 100 & 6.3 & 200 & 12.7 & 50 & 3.4 & 100 & 6.7 & 200 & 13.5 \\
\hline $\mathrm{NH}_{4} \mathrm{H}_{2} \mathrm{PO}_{4}$ & 12.5 & 0.4 & 25 & 0.8 & 50 & 1.6 & 6.25 & 0.2 & 12.5 & 0.4 & 25 & 0.8 \\
\hline $\mathrm{K}_{2} \mathrm{SO}_{4}$ & 25 & 0.6 & 50 & 1.3 & 100 & 2.6 & 12.5 & 0.3 & 25 & 0.6 & 50 & 1.3 \\
\hline & $12: 1: 2$ & & $12: 1:$ & & 12:1: & & & & & & & \\
\hline $\mathrm{NH}_{4} \mathrm{NO}_{3}$ & 50 & 3.4 & 50 & 3.4 & 200 & 13.7 & & & & & & \\
\hline $\mathrm{NH}_{4} \mathrm{H}_{2} \mathrm{PO}_{4}$ & 4.2 & 0.1 & 4.12 & 0.1 & 16.6 & 0.5 & & & & & & \\
\hline$\underline{\mathrm{K}_{2} \mathrm{SO}_{4}}$ & 8.3 & 0.2 & 8.3 & 0.2 & 33.3 & 0.9 & & & & & & \\
\hline
\end{tabular}

${ }^{\mathrm{z}} \mathrm{Micronutrient}$ solutions were identical for all years. Micronutrient solution was the same for all experiments and contained: $0.5 \mathrm{mg} \cdot \mathrm{L}^{-1}(0.009 \mathrm{~mm}) \mathrm{MnCl}_{2} \cdot 4 \mathrm{H}_{2} \mathrm{O}$, $0.1 \mathrm{mg} \cdot \mathrm{L}^{-1}(0.001 \mathrm{~mm})\left(\mathrm{NH}_{4}\right)_{6} \mathrm{Mo}_{7} \mathrm{O}_{24}, 0.05 \mathrm{mg} \cdot \mathrm{L}^{-1}(0.0008 \mathrm{~mm}) \mathrm{ZnSO}_{4} \cdot 7 \mathrm{H}_{2} \mathrm{O}$, and $5 \mathrm{mg} \cdot \mathrm{L}^{-1}(0.09 \mathrm{~mm}) \mathrm{chelated} \mathrm{iron}$.

y $\mathrm{In} 2006,8: 0: 1 \mathrm{~N}: \mathrm{P}: \mathrm{K}\left[100 \mathrm{mg} \cdot \mathrm{L}^{-1}(7.1 \mathrm{~mm})\right.$ from $\mathrm{NH}_{4} \mathrm{NO}_{3}$ and $12.5 \mathrm{mg} \cdot \mathrm{L}^{-1}(0.3 \mathrm{~mm})$ from $\left.\mathrm{K}_{2} \mathrm{SO} 4\right), 12: 1: 0 \mathrm{~N}: \mathrm{P}: \mathrm{K}\left(100 \mathrm{mg} \cdot \mathrm{L}^{-1}(6.9 \mathrm{~mm})\right.$ from NH $\mathrm{NO}_{3}, 8 \mathrm{mg} \cdot \mathrm{L}^{-1}$ $(0.3 \mathrm{~mm})$ from $\mathrm{NH}_{4} \mathrm{H}_{2} \mathrm{PO}_{4}$, and $8 \mathrm{mg} \cdot \mathrm{L}^{-1}(0.3 \mathrm{~mm})$ from Ca$\left.\left(\mathrm{SO}_{4}\right)\right]$, and 1:0:0 N:P:K $\left[100 \mathrm{mg} \cdot \mathrm{L}^{-1}(7.1 \mathrm{~mm})\right.$ from NH $\mathrm{NO}_{3}$, and $8 \mathrm{mg} \cdot \mathrm{L}^{-1}(0.3 \mathrm{~mm})$ from Ca(SO $\left.\left.\mathrm{SO}_{4}\right)\right]$ were included as treatments for comparison purposes.

$\mathrm{N}=$ nitrogen; $\mathrm{P}=$ phosphorus; $\mathrm{K}=$ potassium. 
complete block design (RCBD) with six replications. The main factors were two species (hibiscus and rudbeckia) and six treatments consisting of either six N:P or six N:K ratios. Six N:P ratios $(1: 1,2: 1,4: 1,8: 1,16: 1$, or $32: 1)$ were evaluated with the $\mathrm{N}$ and $\mathrm{K}$ concentrations held constant at 100 and $50 \mathrm{mg} \cdot \mathrm{L}^{-1}$, respectively, resulting in $\mathrm{P}$ concentrations of 100, 50, $25,12.5,6.25$, or $3.13 \mathrm{mg} \cdot \mathrm{L}^{-1}$. Six $\mathrm{N}: \mathrm{K}$ ratios $(1: 2,1: 1,2: 1,4: 1,8: 1$, or $16: 1)$ with $\mathrm{N}$ and $\mathrm{P}$ concentrations held constant at 100 and 25 $\mathrm{mg} \cdot \mathrm{L}^{-1}$, respectively, evaluated $\mathrm{K}$ concentrations of $200,100,50,25,12.5$, and $6.25 \mathrm{mg} \cdot \mathrm{L}^{-1}$. For both experiments, rudbeckia and hibiscus were potted on $8 \mathrm{Apr}$. and $15 \mathrm{Apr}$., respectively. Fertigation for each experiment began 23 May with harvest on 27 July and 5 Aug. for hibiscus and rudbeckia, respectively. For both $\mathrm{N}: \mathrm{K}$ and $\mathrm{N}: \mathrm{P}$ experiments, substrate $\mathrm{EC}$ and $\mathrm{pH}$ were measured at treatment initiation and every 2 weeks thereafter (Table 2).

Nitrogen:phosphorus:potassium ratio experiment holding nitrogen concentration constant (2006). Based on results from the 2005 experiments, a $2 \times 6 \times 6$ factorial experiment in a RCBD with six replications was conducted in 2006. The main effects were two species (hibiscus and rudbeckia) with six concentrations of $\mathrm{P}\left(50,33,25,12.5,8\right.$, or $\left.4 \mathrm{mg} \cdot \mathrm{L}^{-1}\right)$ and six concentrations of $\mathrm{K}(100,66,50,25,16$, or $\left.8 \mathrm{mg} \cdot \mathrm{L}^{-1}\right)$ producing six $\mathrm{N}: \mathrm{P}: \mathrm{K}$ ratios $(2: 1: 2$, $3: 1: 2,4: 1: 2,8: 1: 2,12: 1: 2$, and $24: 1: 2$ ) with the concentration of $\mathrm{N}$ held constant at 100 $\mathrm{mg} \cdot \mathrm{L}^{-1}$. Plants were potted 11 May and fertigation began 22 May. Hibiscus and rudbeckia were harvested 14 July and 21 July, respectively. Substrate EC and $\mathrm{pH}$ were measured at treatment initiation and every 3 weeks thereafter (Table 2).

Nitrogen concentrations and nitrogen: phosphorus:potassium ratio experiment (2007). Because concentration of $\mathrm{P}$ and $\mathrm{K}$ along with ratio of nutrients affected plant growth in 2006, a factorial arrangement of three $\mathrm{N}$ concentrations $\times$ three $\mathrm{N}: \mathrm{P}: \mathrm{K}$ ratios in a RCBD with six replications was evaluated during Summer 2007. Nitrogen concentrations of 200, 100, or $50 \mathrm{mg} \cdot \mathrm{L}^{-1}$ were combined with $\mathrm{P}$ concentrations of $50,25,16.7,12.5,8,6.3$, or $4.2 \mathrm{mg} \cdot \mathrm{L}^{-1}$ and $\mathrm{K}$ concentrations of 100,50 , $33.3,25,16,12.5$, or $8.3 \mathrm{mg} \cdot \mathrm{L}^{-1}$ resulting in $\mathrm{N}: \mathrm{P}: \mathrm{K}$ ratios of $4: 1: 2,8: 1: 2$, and $12: 1: 2$. The plants were potted 1 May, fertigation began 14 May, and hibiscus and rudbeckia were harvested 23 July. Substrate EC and $\mathrm{pH}$ were measured at treatment initiation and every 2 weeks thereafter (Table 2).

\section{Results and Discussion}

Nitrogen:phosphorus ratio (2005). Stem and flower dry weights, number of flowers, and leaf area of both species were unaffected by species $\times \mathrm{N}: \mathrm{P}$ ratio, N:P ratio, and $\mathrm{P}$

Table 2. Substrate solution $\mathrm{pH}$ and electrical conductivity (EC) for each nutrition experiment. ${ }^{2}$

\begin{tabular}{|c|c|c|c|}
\hline $\mathrm{N}: \mathrm{P}$ ratio $(2005)$ & $\mathrm{P}$ concn $\left(\mathrm{mg} \cdot \mathrm{L}^{-1}\right)^{\mathrm{y}}$ & $\mathrm{pH}$ & $\mathrm{EC}\left(\mathrm{dS} \cdot \mathrm{m}^{-1}\right)$ \\
\hline $32: 1$ & 3.13 & 5.5 & 0.33 \\
\hline $16: 1$ & 6.25 & 5.4 & 0.34 \\
\hline $8: 1$ & 12.5 & 5.5 & 0.31 \\
\hline $4: 1$ & 25 & 5.4 & 0.32 \\
\hline $2: 1$ & 50 & 5.0 & 0.38 \\
\hline $1: 1$ & 100 & 5.3 & 0.38 \\
\hline $\mathrm{N}: \mathrm{K}$ ratio $(2005)$ & $\mathrm{K}$ concn $\left(\mathrm{mg} \cdot \mathrm{L}^{-1}\right)^{\mathrm{x}}$ & & \\
\hline $16: 1$ & 6.25 & 5.4 & 0.25 \\
\hline $8: 1$ & 12.5 & 5.5 & 0.29 \\
\hline $4: 1$ & 25 & 5.4 & 0.33 \\
\hline $2: 1$ & 50 & 5.4 & 0.42 \\
\hline $1: 1$ & 100 & 5.3 & 0.56 \\
\hline $1: 2$ & 200 & 5.4 & 0.45 \\
\hline $\mathrm{N}: \mathrm{P}: \mathrm{K} / \mathrm{N}$ held constant (2006) & $\mathrm{P} / \mathrm{K}$ concn $\left(\mathrm{mg} \cdot \mathrm{L}^{-1}\right)^{\mathrm{w}}$ & & \\
\hline $24: 1: 2$ & $4 / 8$ & 5.2 & 0.33 \\
\hline $12: 1: 2$ & $8 / 16$ & 5.3 & 0.31 \\
\hline $8: 1: 2$ & $12.5 / 25$ & 5.4 & 0.30 \\
\hline $4: 1: 2$ & $25 / 50$ & 5.2 & 0.34 \\
\hline $3: 1: 2$ & $33 / 66$ & 5.2 & 0.35 \\
\hline $2: 1: 2$ & $50 / 100$ & 5.0 & 0.44 \\
\hline $\mathrm{N}$ concn/N:P:K ratios (2007) & $\mathrm{P} / \mathrm{K}$ concn $\left(\mathrm{mg} \cdot \mathrm{L}^{-1}\right)$ & & \\
\hline $50 \mathrm{mg} \cdot \mathrm{L}^{-1} / 4: 1: 2$ & $12.5 / 25$ & 5.8 & 0.25 \\
\hline $100 \mathrm{mg} \cdot \mathrm{L}^{-1} / 4: 1: 2$ & $25 / 50$ & 5.4 & 0.30 \\
\hline $200 \mathrm{mg} \cdot \mathrm{L}^{-1} / 4: 1: 2$ & $50 / 100$ & 5.1 & 0.62 \\
\hline $50 \mathrm{mg} \cdot \mathrm{L}^{-1} / 8: 1: 2$ & $6.25 / 12.5$ & 5.7 & 0.23 \\
\hline $100 \mathrm{mg} \cdot \mathrm{L}^{-1} / 8: 1: 2$ & $12.5 / 25$ & 5.5 & 0.27 \\
\hline $200 \mathrm{mg} \cdot \mathrm{L}^{-1} / 8: 1: 2$ & $25 / 50$ & 5.2 & 0.47 \\
\hline $50 \mathrm{mg} \cdot \mathrm{L}^{-1} / 12: 1: 2$ & $4.17 / 8$ & 5.7 & 0.25 \\
\hline $100 \mathrm{mg} \cdot \mathrm{L}^{-1} / 12: 1: 2$ & $8 / 16$ & 5.5 & 0.27 \\
\hline $200 \mathrm{mg} \cdot \mathrm{L}^{-1} / 12: 1: 2$ & $16.67 / 33$ & 5.3 & 0.46 \\
\hline
\end{tabular}

${ }^{\mathrm{z}}$ Species $\times$ treatment interactions were non-significant; thus, data are averaged over species. Additionally, trends in treatment effects were similar across sampling thus averages across sample date are presented.

${ }^{\mathrm{y}} \mathrm{N}$ and $\mathrm{K}$ concentrations held constant at 100 and $50 \mathrm{mg} \cdot \mathrm{L}^{-1}$, respectively.

${ }^{\mathrm{x}} \mathrm{N}$ and $\mathrm{P}$ concentrations held constant at 100 and $25 \mathrm{mg} \cdot \mathrm{L}^{-1}$, respectively.

${ }^{\mathrm{w}} \mathrm{N}$ concentration held constant at $100 \mathrm{mg} \cdot \mathrm{L}^{-1}$.

$\mathrm{N}=$ nitrogen; $\mathrm{P}=$ phosphorus; $\mathrm{K}=$ potassium . concentration (data not presented). Thus, these parameters responded similarly across a wide range of $\mathrm{N}: \mathrm{P}$ ratio and $\mathrm{P}$ concentrations. Zhang et al. (2004) also reported that flowering of Scaevola aemula 'New Wonder' was unaffected by concentrations of $\mathrm{P}$ ranging from 0 to $43.5 \mathrm{mg} \cdot \mathrm{L}^{-1}$. In addition, substrate $\mathrm{pH}$ and $\mathrm{EC}$ were unaffected by species $\times \mathrm{N}: \mathrm{P}$ ratio (data not presented). Substrate solution $\mathrm{pH}$ was unaffected by N:P ratio, whereas EC increased slightly as $\mathrm{N}: \mathrm{P}$ ratio decreased ( $\mathrm{P}$ concentration increased) (Table 2). However, the species $\times \mathrm{N}$ :P ratio interaction was significant for leaf, root, and total dry weights so results were reanalyzed by species. In addition, total dry weight of each species responded similarly to leaf and root dry weight so only total dry weight is presented.

Total dry weight of hibiscus responded quadratically to decreasing N:P ratio (increasing $\mathrm{P}$ concentration) with a calculated maximum growth attained with a $5: 1 \mathrm{~N}: \mathrm{P}$ ratio and $20 \mathrm{mg} \cdot \mathrm{L}^{-1} \mathrm{P}$ (Fig. 1). The $1: 1 \mathrm{~N}: \mathrm{P}$ ratio $\left(100 \mathrm{mg} \cdot \mathrm{L}^{-1} \mathrm{P}\right)$ resulted in a substantial decrease in growth. Similarly, Zhang et al. (2004) reported growth of Scaevola aemula 'New Wonder' was reduced when fertilized with greater than $44 \mathrm{mg} \cdot \mathrm{L}^{-1} \mathrm{P}(4: 1 \mathrm{~N}: \mathrm{P}$ ratio). Euphorbia pulcherrima Wind., Hordeum vulgare L., and some cultivars of Glycine max L. are also reported to be sensitive to high $\mathrm{P}$ (Foote and Howell, 1964; Richard and Rees, 1962; Whipker and Hammer, 1994). When the 1:1 N:P (100 $\left.\mathrm{mg} \cdot \mathrm{L}^{-1} \mathrm{P}\right)$ data were removed and the data reanalyzed, all significance was lost. Thus, hibiscus grew similarly when fertigated with $\mathrm{N}: \mathrm{P}$ ratios ranging from $2: 1$ to $32: 1 \mathrm{~N}: \mathrm{P}$ (50 to $3.1 \mathrm{mg} \cdot \mathrm{L}^{-1} \mathrm{P}$ ). Ilex crenata Thunb. 'Helleri', a woody perennial, and Hakonechloa macra 'Aureola', a herbaceous ornamental grass, also grew well with lower $\mathrm{P}$ concentrations (10 and $8 \mathrm{mg} \cdot \mathrm{L}^{-1} \mathrm{P}$, respectively) and higher N:P ratios (10:1 or 20:1) (Harvey et al., 2004; Yeager and Wright, 1982). In contrast, Hipp et al. (1988, 1989) reported maximum growth of Melampodium leucanthum and Salvia greggii occurred between $\mathrm{P}$ concentrations of 30 and $50 \mathrm{mg} \cdot \mathrm{L}^{-1}$ and $4: 1$ to $5.5: 1 \mathrm{~N}: \mathrm{P}$ ratios.

Foliar $\mathrm{N}$ and $\mathrm{P}$ concentration of hibiscus responded quadratically to decreasing $\mathrm{N}: \mathrm{P}$ ratio (increasing $\mathrm{P}$ concentration), whereas foliar $\mathrm{K}$ (mean, 2.2\%), Ca (mean, 2.1\%), Mg (mean, $1.0 \%$ ) and $\mathrm{S}$ (mean, $0.4 \%$ ) concentrations were unaffected by $\mathrm{N}: \mathrm{P}$ ratio $(\mathrm{Ca}, \mathrm{Mg}$, and $\mathrm{S}$ data not presented) (Fig. 1). Additionally, foliar $\mathrm{Fe}, \mathrm{Mn}, \mathrm{Cu}, \mathrm{B}$, and sodium $(\mathrm{Na})$ concentrations were unaffected by N:P ratio; whereas, $\mathrm{Zn}$ concentration decreased as $\mathrm{P}$ concentration increased (N:P ratio decreased) (data not presented). In contrast to total dry weight, when the $1: 1 \mathrm{~N}: \mathrm{P}\left(100 \mathrm{mg} \cdot \mathrm{L}^{-1} \mathrm{P}\right)$ was removed from the analyses, foliar $\mathrm{N}$ and foliar $\mathrm{P}$ concentrations were still affected by $\mathrm{N}: \mathrm{P}$ ratio and increased linearly as $\mathrm{P}$ concentration increased (N:P ratio decreased). Because growth was maintained over a wide range of $\mathrm{N}: \mathrm{P}$ ratios, it may be possible to fertilize hibiscus with as little as $3.1 \mathrm{mg} \cdot \mathrm{L}^{-1}$ $\mathrm{P}$ (32:1 N:P). In addition, foliar $\mathrm{N}, \mathrm{P}$, and $\mathrm{K}$ concentrations of $2.4 \%, 0.4 \%$, and $2.2 \%$, 
respectively, would be adequate to achieve $90 \%$ of maximum growth (Fig. 1).

Similar to hibiscus, total dry weight of rudeckia was unaffected by $\mathrm{N}: \mathrm{P}$ ratio (Fig. 2). Thus, maximum dry weight was obtained with $\mathrm{N}: \mathrm{P}$ ratios ranging from $1: 1$ to $32: 1$ (100 to $3.1 \mathrm{P} \mathrm{mg} \cdot \mathrm{L}^{-1}$ ). However, unlike hibiscus, rudbeckia was not negatively affected by high $\mathrm{N}: \mathrm{P}$ ratios $\left(1: 1,100 \mathrm{mg} \cdot \mathrm{L}^{-1} \mathrm{P}\right)$ and maximum growth was predicted with 46 $\mathrm{mg} \cdot \mathrm{L}^{-1} \mathrm{P}(2: 1 \mathrm{~N}: \mathrm{P}$ ratio).

Foliar $\mathrm{N}$ and $\mathrm{P}$ concentrations of rudbeckia increased linearly with decreasing $\mathrm{N}: \mathrm{P}$ ratio (increasing $\mathrm{P}$ concentration), whereas foliar $\mathrm{K}$ concentration decreased linearly with decreasing N:P ratio (increasing $\mathrm{P}$ concentration) (Fig. 2). Similar to hibiscus, foliar $\mathrm{Ca}$ (mean, $2.8 \%$ ), $\mathrm{Mg}$ (mean, $1.0 \%$ ), and $\mathrm{S}$ (mean, $0.7 \%$ ) concentrations and foliar $\mathrm{Fe}$, $\mathrm{Mn}, \mathrm{Zn}, \mathrm{B}$, and $\mathrm{Na}$ (data not presented) were unaffected by N:P ratio. Harvey et al. (2004) reported similar results to trends reported here with foliar $\mathrm{N}, \mathrm{P}, \mathrm{Ca}$, and $\mathrm{Mg}$ concentrations of Hakonechloa macra 'Aureola' when grown with N:P ratios from 5:1 to 20:1. Yeager and Wright (1982) also reported increased foliar P levels with increased P concentration without an equivalent increase in growth of 'Helleri' holly. The aforementioned authors attributed the increased $\mathrm{P}$ uptake to luxury consumption.

Nitrogen:potassium ratio (2005). Substrate $\mathrm{pH}$ and EC, leaf, stem, root, and total dry weights and leaf area were unaffected by the species $\times \mathrm{N}: \mathrm{K}$ interaction (data not presented). Thus, only main effects, averaged over species, are presented. Substrate solution $\mathrm{pH}$ was unaffected by $\mathrm{N}: \mathrm{K}$ ratio, whereas EC increased as $\mathrm{N}: \mathrm{K}$ ratio decreased ( $\mathrm{K}$ concentration increased) (Table 2). Total dry weight was representative of the stem and root dry weight response so only total dry weight is presented. Total dry weight increased linearly as $\mathrm{K}$ concentration increased to $200 \mathrm{mg} \cdot \mathrm{L}^{-1} \mathrm{~K}$ and $\mathrm{N}: \mathrm{K}$ ratio decreased to $1: 2$; however, plants fertilized with a $16: 1 \mathrm{~N}: \mathrm{K}\left(6.25 \mathrm{mg} \cdot \mathrm{L}^{-1} \mathrm{~K}\right)$ ratio achieved $90 \%$ of maximum growth (Fig. 3). Soundy et al. (2001) found that lettuce (Lactuca sativa L.) shoot growth was unaffected by $\mathrm{K}$ concentrations between 0 and $60 \mathrm{mg} \cdot \mathrm{L}^{-1} \mathrm{~K}$ and Melton and Dufault (1991) reported that tomato (Lycopersicon esculentum Mill. var. esculentum) growth was unaffected by K concentrations of 25,75 , and $225 \mathrm{mg} \cdot \mathrm{L}^{-1}$. Thus, it may be possible to produce adequate growth with dramatically reduced $\mathrm{N}: \mathrm{K}$ ratio and $\mathrm{K}$ concentrations.

Foliar K (Fig. 3), S, and Fe (data not presented) concentrations of hibiscus increased with decreasing $\mathrm{N}: \mathrm{K}$ ratio (increasing $\mathrm{K}$ concentration), whereas foliar $\mathrm{Ca}, \mathrm{Mg}$, and $\mathrm{B}$ concentrations of hibiscus decreased linearly with decreasing $\mathrm{N}: \mathrm{K}$ ratio (increasing $\mathrm{K}$ concentration) (data not presented). Calcium and $\mathrm{Mg}$ were not provided by fertigation and were only supplied by initially amending the substrate with dolomitic lime. Thus, as plant growth increased, uptake of $\mathrm{Ca}$ and $\mathrm{Mg}$ did not increase proportionally. There was a quadratic response in foliar $\mathrm{P}$ concentration with maximum foliar $\mathrm{P}$ concentration attained with $25 \mathrm{mg} \cdot \mathrm{L}^{-1} \mathrm{~K}$ and

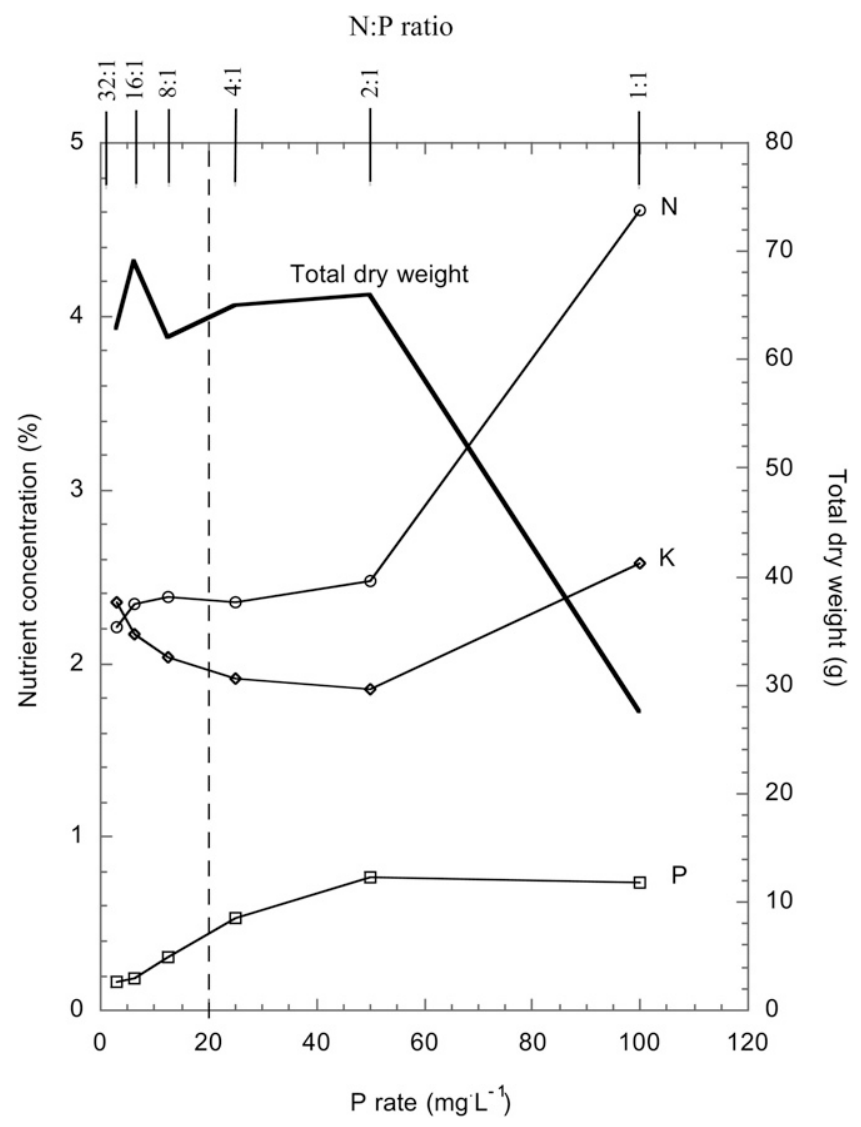

Fig. 1. Effects of phosphorus $(\mathrm{P})$ concentration and nitrogen $(\mathrm{N})$ :P ratio on nutrient concentration and total plant dry weight of 'Luna Blush' hibiscus (2005). $\mathrm{N}$ and potassium $(\mathrm{K})$ concentrations held constant at $100 \mathrm{mg} \cdot \mathrm{L}^{-1}$ and $50 \mathrm{mg} \cdot \mathrm{L}^{-1}$, respectively. Vertical dashed line represents the calculated $\mathrm{P}$ concentration required to achieve maximum growth. Data are means of six observations.

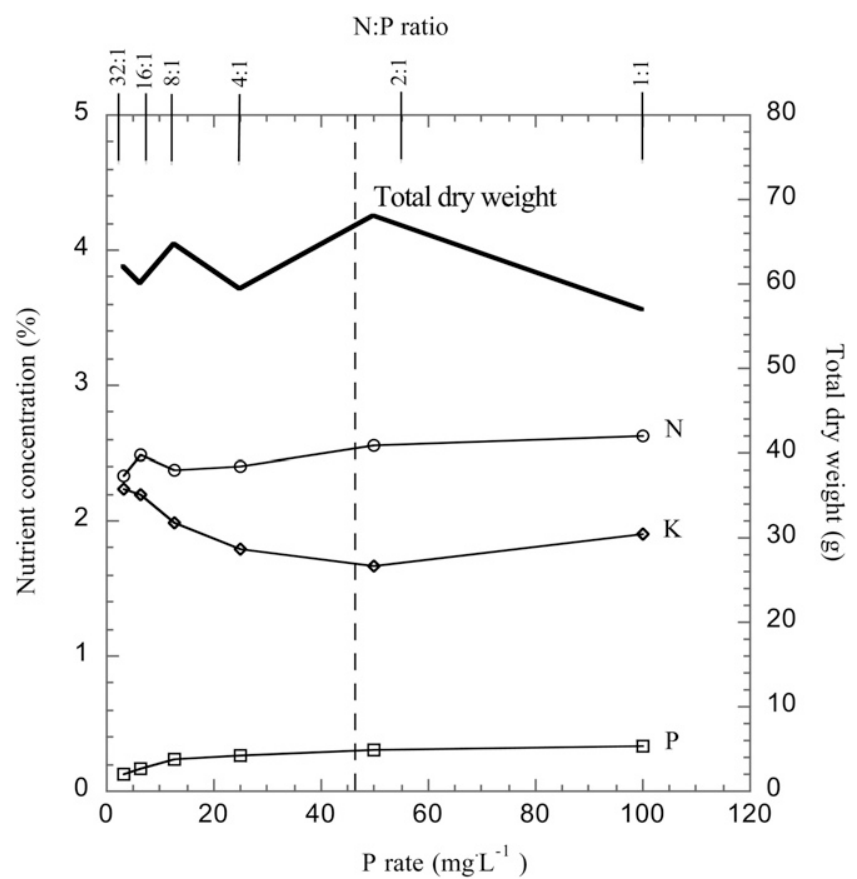

Fig. 2. Effects of phosphorus $(\mathrm{P})$ concentration and nitrogen $(\mathrm{N})$ :P ratio on nutrient concentration and total plant dry weight of 'Goldsturm' rudbeckia (2005). N and potassium (K) concentrations held constant at $100 \mathrm{mg} \cdot \mathrm{L}^{-1}$ and $50 \mathrm{mg} \cdot \mathrm{L}^{-1}$, respectively. Vertical dashed line represents the calculated $\mathrm{P}$ concentration required to achieve maximum growth. Total dry weight of rudbeckia unaffected by $\mathrm{P}$ concentration. Data are means of six observations. 
a 4:1 N:K ratio (Fig. 3). Foliar N (Fig. 3), Zn, and $\mathrm{Cu}$ concentrations were unaffected by $\mathrm{N}: \mathrm{K}$ ratio (data not presented). Based on foliar nutrient concentration and growth, a $4: 1 \mathrm{~N}: \mathrm{K}$ ratio with $100 \mathrm{mg} \cdot \mathrm{L}^{-1} \mathrm{~N}$ and $25 \mathrm{mg} \cdot \mathrm{L}^{-1} \mathrm{~K}$ and $2.4 \% \mathrm{~N}, 0.4 \% \mathrm{P}$, and $2.4 \% \mathrm{~K}$ provided maximum growth of hibiscus.

Similar to hibiscus, foliar K (Fig. 3) and S (data not presented) concentrations of rudbeckia increased with decreasing $\mathrm{N}: \mathrm{K}$ ratio (increasing $\mathrm{K}$ concentration), whereas foliar $\mathrm{P}$, $\mathrm{Ca}, \mathrm{Mg}, \mathrm{Zn}$, and $\mathrm{Cu}$ concentrations decreased with decreasing $\mathrm{N}: \mathrm{K}$ ratio (increasing $\mathrm{K}$ concentration), and foliar N, Fe, and B (Fig. 3) concentrations were unaffected by $\mathrm{N}: \mathrm{K}$ ratio. Yeager and Wright (1982) reported interactions between cationic micronutrients ( $\mathrm{Fe}, \mathrm{Zn}$, and $\mathrm{Mn}$ ) and $\mathrm{P}$ concentration. No such micronutrient accumulation reductions were found in our research (data not presented). Maximum growth of rudbeckia was achieved with foliar nutrient concentrations of $2.4 \% \mathrm{~N}, 0.2 \%$ P, and 3.2\% K (Fig. 3).

Nitrogen:phosphorus:potassium ratio with nitrogen held constant (2006). Substrate $\mathrm{pH}$ and EC were unaffected by the species $\times$ nutrient ratio interaction; thus, data are averaged over species. Substrate $\mathrm{pH}$ remained constant, whereas EC increased as N:P:K ratio decreased ( $\mathrm{P}$ and $\mathrm{K}$ concentrations increased) (Table 2). Root, flower bud, and total dry weights were significantly affected by the species $\times$ nutrient ratio interaction so data were reanalyzed by species (data not presented). In contrast, number of flower buds, leaf dry weight, and leaf area were unaffected by the species $x$ ratio interaction so only main effects of species and ratio are presented. Number of flower buds, leaf dry weight, and leaf area increased linearly with decreasing N:P:K ratio (increasing $\mathrm{P}$ and $\mathrm{K}$ concentrations) to a maximum at a ratio of 2:1:2 (data not presented). However, for all three parameters, there appeared to be a maximum threshold between 8:1:2 and 12:1:2 as number of flowers, leaf dry weight, and leaf area only decreased $7 \%, 4 \%$ and $7 \%$, respectively, from the maximum at 2:1:2 to $8: 1: 2$, whereas number of flowers, leaf dry weight, and leaf area when grown with 12:1:2 decreased $27 \%, 14 \%$, and $39 \%$, respectively, from the maximum at $2: 1: 2$. The $\mathrm{N}, \mathrm{P}$, and $\mathrm{K}$ concentrations at 8:1:2 $\left(100 \mathrm{mg} \cdot \mathrm{L}^{-1} \mathrm{~N}, 12.5\right.$ $\mathrm{mg} \cdot \mathrm{L}^{-1} \mathrm{P}$, and $25 \mathrm{mg} \cdot \mathrm{L}^{-1} \mathrm{~K}$ ) are similar to those recommended by Wright and Niemiera (1985) for production of 'Helleri' holly. In 2005, a similar N:K ratio maximized growth; however, much higher ratios of N:P (16:1 N:P for hibiscus and 32:1 N:P for rudbeckia) resulted in greater growth.

Total dry weight of each species accurately reflected root, stem, and flower bud dry weights so only total dry weight is presented. Total dry weight of hibiscus and rudbeckia increased linearly as $\mathrm{N}: \mathrm{P}: \mathrm{K}$ ratio decreased (increasing $\mathrm{P}$ and $\mathrm{K}$ concentrations) (Figs. 4 and 5).

However, similar to flower bud number and leaf area, total dry weights of hibiscus and rudbeckia were not reduced to less than $90 \%$ of maximum until the N:P:K solution ratio increased to $12: 1: 2\left(8 \mathrm{mg} \cdot \mathrm{L}^{-1} \mathrm{P}, 16 \mathrm{mg} \cdot \mathrm{L}^{-1} \mathrm{~K}\right)$. When 12:1:2 and 24:1:2 ratios were removed

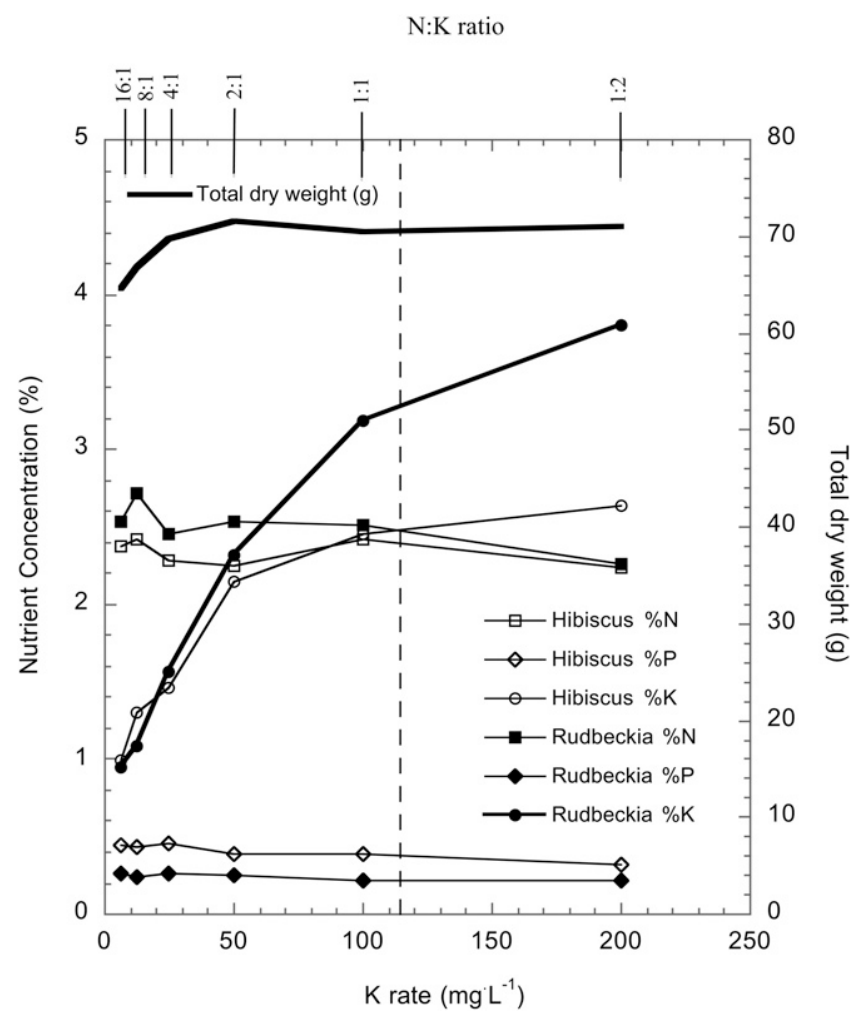

Fig. 3. Effects of potassium $(\mathrm{K})$ concentration and nitrogen $(\mathrm{N}): \mathrm{K}$ ratio on nutrient concentration and total plant dry weight of 'Luna Blush' hibiscus and 'Goldsturm' rudbeckia (2005). N and phosphorus (P) concentrations held constant at $100 \mathrm{mg} \cdot \mathrm{L}^{-1}$ and $25 \mathrm{mg} \cdot \mathrm{L}^{-1}$, respectively. Vertical dashed line represents the calculated $\mathrm{K}$ concentration required to achieve maximum growth. Nonsignificant $\mathrm{N}: \mathrm{K}$ ratio $\times$ species interaction for dry weight. Data are means of six observations.

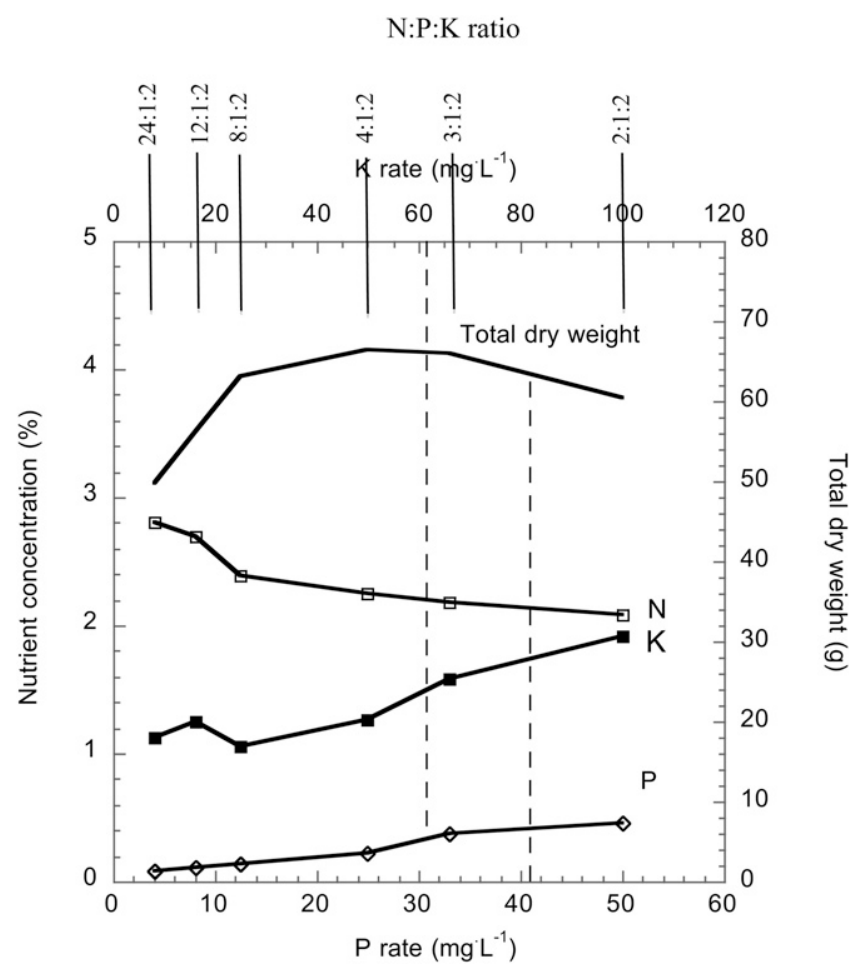

Fig. 4. Effects of phosphorus $(\mathrm{P})$ and potassium $(\mathrm{K})$ concentrations and nitrogen $(\mathrm{N}): \mathrm{P}: \mathrm{K}$ ratio on total plant dry weight of 'Luna White' hibiscus (2006). N concentration held constant at $100 \mathrm{mg} \cdot \mathrm{L}^{-1}$. Vertical dashed lines represents the calculated $\mathrm{P}$ and $\mathrm{K}$ concentrations required to achieve maximum growth. Data are means of six observations. 
from the analysis, total dry weights of both species were unaffected by nutrient ratio indicating similar growth was obtained with nutrient ratios ranging from $2: 1: 2$ to $8: 1: 2$. Other studies have reported that low concentrations of $\mathrm{K}$ were adequate to support plant growth. Melton and Dufault (1991) reported growth of tomato transplants was unaffected by $\mathrm{K}$ concentration $\left(25,75\right.$, or $\left.225 \mathrm{mg} \cdot \mathrm{L}^{-1} \mathrm{~K}\right)$ but required relatively high concentrations of $\mathrm{N}$ and $\mathrm{P}$ (225 and $45 \mathrm{mg} \cdot \mathrm{L}^{-1} \mathrm{~N}$ and $\mathrm{P}$, respectively) in a 9:1.8:1 N:P:K ratio. Rodriguez et al. (2002) reported a ratio of 1:0:0.8 or 1:0:1.7 $\mathrm{N}: \mathrm{P}: \mathrm{K}$ was sufficient to support bermudagrass [Cynodon dactylon (L.) Pers. $\times$ C. transvaalensis Burt-Davy] during establishment (root growth) and ratios higher than 1:0:0.8 N:P:K decreased shoot growth.

Foliar $\mathrm{N}$ concentration for both species decreased linearly with decreasing N:P:K ratio (increasing $\mathrm{P}$ and $\mathrm{K}$ concentrations) (Figs. 4 and 5), possibly as a result of dilution because the $\mathrm{N}$ concentration was constant and growth increased with increasing $\mathrm{P}$ and $\mathrm{K}$ concentrations. In contrast, foliar P, K, and S (data not presented) concentrations increased linearly with decreasing N:P:K ratio (increasing $\mathrm{P}$ and K) for both hibiscus and rudbeckia (Figs. 4 and 5). Foliar $\mathrm{Ca}$ (mean, $1.7 \%$ and $2.3 \%$ for hibiscus and rudbeckia, respectively) and $\mathrm{Mg}$ (mean, $0.8 \%$ and $0.8 \%$ for hibiscus and rudbeckia, respectively) concentrations were not impacted by N:P:K ratio (data now presented). Foliar nutrient concentrations of $2.2 \% \mathrm{~N}, 0.4 \%$ $\mathrm{P}$, and $1.4 \% \mathrm{~K}$ were required for maximum growth of hibiscus (Fig. 4), whereas nutrient concentrations of $2.2 \% \mathrm{~N}, 0.2 \% \mathrm{P}$, and $1.8 \% \mathrm{~K}$ were needed for maximum growth of rudbeckia (Fig. 5). Mills and Jones (1996) reported slightly lower foliar N (2.0\%) and slightly higher foliar $\mathrm{N}(2.4 \%)$ and foliar $\mathrm{P}(0.4 \%$, $0.4 \%)$ and higher foliar K $(2.9 \%, 2.1 \%)$ concentrations for Hibiscus coccineus Walt. and Rudbeckia fulgida var. sullivantii 'Goldsturm', respectively. Although similar foliar mineral nutrient concentrations were required to maximize growth of both hibiscus and rudbeckia, rudbeckia required lower $\mathrm{P}$ and higher $\mathrm{K}$ concentrations in fertilizer solutions because maximum total dry weight of rudbeckia was achieved with $100 \mathrm{mg} \cdot \mathrm{L}^{-1} \mathrm{~N}, 36 \mathrm{mg} \cdot \mathrm{L}^{-1} \mathrm{P}$, and $72 \mathrm{mg} \cdot \mathrm{L}^{-1}$ $\mathrm{K}$ in a 2.8:1:1.4 N:P:K ratio (Fig. 5), whereas maximum dry weight for hibiscus was obtained with a fertilizer solution containing $100 \mathrm{mg} \cdot \mathrm{L}^{-1}$ $\mathrm{N}, 43 \mathrm{mg} \cdot \mathrm{L}^{-1} \mathrm{P}$, and $62 \mathrm{mg} \cdot \mathrm{L}^{-1} \mathrm{~K}$ in a 2.3:1:1.6 $\mathrm{N}: \mathrm{P}: \mathrm{K}$ ratio (Fig. 4).

Based on foliar mineral nutrient concentrations, a 2:1:2 N:P:K ratio was required for nutrient solutions applied to hibiscus and a 3:1:2 N:P:K ratio for rudbeckia. However, growth of both species was similar over a range of N:P:K ratios even as high as 8:1:2. Therefore, optimum growth of both species may occur with higher $\mathrm{N}: \mathrm{P}: \mathrm{K}$ ratios and lower $\mathrm{P}$ and $\mathrm{K}$ concentrations if an appropriate $\mathrm{N}$ concentration is also determined. Both Harvey et al. (2004) and Soundy et al. (2001) indicated optimum tissue nutrient levels should be evaluated over a range of fertilizer treatments. Data here have been produced with a fixed $\mathrm{N}$ concentration of $100 \mathrm{mg} \cdot \mathrm{L}^{-1}$; therefore, our last experiment consisted of three $\mathrm{N}$ concentrations in combination with three $\mathrm{N}: \mathrm{P}: \mathrm{K}$ ratios.

Nitrogen concentrations and nitrogen: phosphorus:potassium ratios (2007). Analyses of these data showed a significant species $x$ $\mathrm{N}$ concentration $\times \mathrm{N}: \mathrm{P}: \mathrm{K}$ ratio interaction so the data were reanalyzed by species. Substrate $\mathrm{pH}$ and $\mathrm{EC}$ did not vary by species so the data were averaged over species. For all N:P:K ratios, substrate $\mathrm{pH}$ decreased slightly and $\mathrm{EC}$ increased as $\mathrm{N}$ concentration increased (Table 2). For hibiscus, the $\mathrm{N}$ concentration $\times \mathrm{N}: \mathrm{P}: \mathrm{K}$ ratio interaction was significant for all growth variables measured except number of flower buds (data not presented). The highest $\mathrm{N}$ concentration $\left(200 \mathrm{mg} \cdot \mathrm{L}^{-1}\right)$ resulted in the greatest number of flower buds, whereas number of flower buds was unaffected by $\mathrm{N}: \mathrm{P}: \mathrm{K}$ ratio (data not presented).

Similar to our previous studies, total dry weight accurately reflected all dry weight responses. Within each N:P:K ratio, total dry weight of hibiscus increased with increasing $\mathrm{N}$ concentration (Table 3 ). Within $50 \mathrm{mg} \cdot \mathrm{L}^{-1} \mathrm{~N}$,

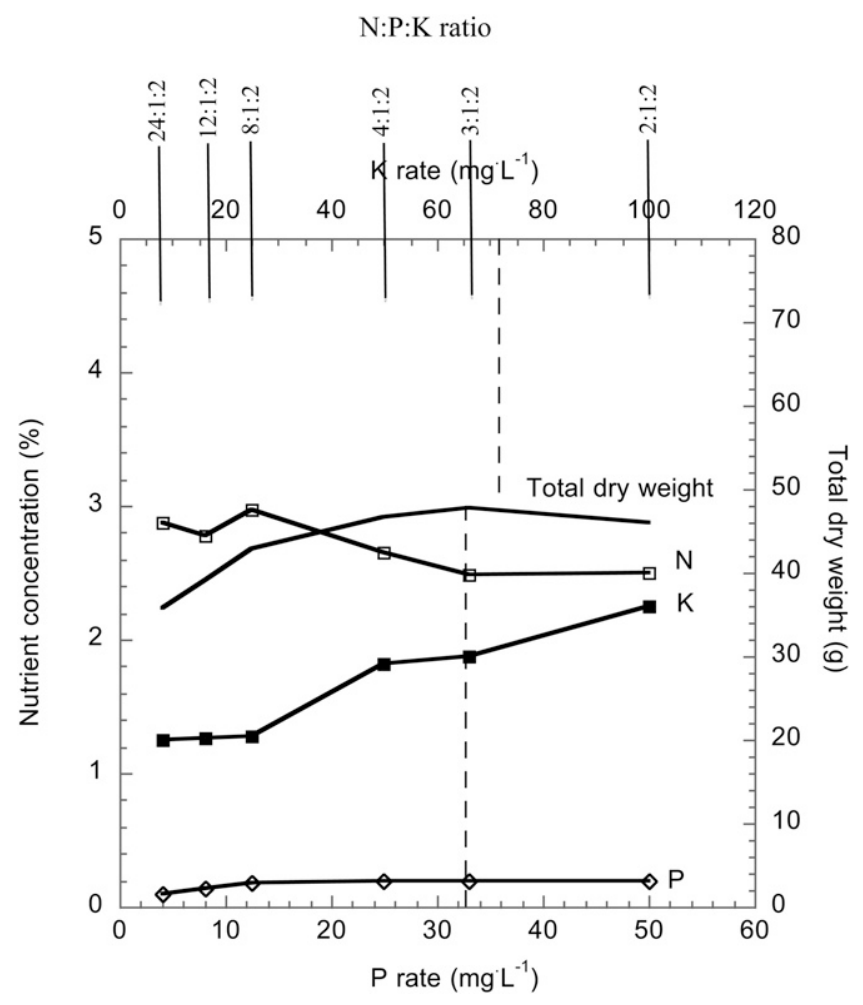

Fig. 5. Effects of phosphorus $(\mathrm{P})$ and potassium $(\mathrm{K})$ concentrations and nitrogen $(\mathrm{N}): \mathrm{P}: \mathrm{K}$ ratio on total plant dry weight of 'Goldsturm' rudbeckia (2006). N concentration held constant at $100 \mathrm{mg} \cdot \mathrm{L}^{-1}$. Vertical dashed lines represents the calculated $\mathrm{P}$ and $\mathrm{K}$ concentrations required to achieve maximum growth. Data are means of six observations.

Table 3. Effect of $\mathrm{N}: \mathrm{P}: \mathrm{K}$ ratio within each $\mathrm{N}$ concentration and $\mathrm{N}$ concentration within each $\mathrm{N}: \mathrm{P}: \mathrm{K}$ ratio on growth and foliar N concentration of 'Luna Red' hibiscus (2007). ${ }^{\mathrm{z}}$

\begin{tabular}{lccccc}
\hline $\begin{array}{l}\mathrm{N}: \mathrm{P}: \mathrm{K} \text { ratios } \\
\text { within N concn }\end{array}$ & $\begin{array}{c}\text { Total dry } \\
\text { wt }(\mathrm{g})\end{array}$ & $\begin{array}{c}\mathrm{N} \\
(\%)\end{array}$ & $\begin{array}{c}\text { N concn within } \\
\mathrm{N}: \mathrm{P}: \mathrm{K} \text { ratio }\end{array}$ & $\begin{array}{c}\text { Total dry } \\
\text { wt }(\mathrm{g})\end{array}$ & $\begin{array}{c}\mathrm{N} \\
(\%)\end{array}$ \\
\hline $50\left(\mathrm{mg} \cdot \mathrm{L}^{-1}\right)$ & & & $4: 1: 2$ & & \\
$4: 1: 2$ & $19.2^{* \mathrm{y}}$ & 2.6 & 50 & $19.2^{*}$ & $2.6^{*}$ \\
$8: 1: 2$ & $25.9^{* *}$ & 2.5 & 100 & $36.6^{* *}$ & $2.8^{*}$ \\
$12: 1: 2$ & $27.1^{* *}$ & 2.5 & 200 & $57.5^{* * *}$ & $3.9^{* *}$ \\
ANOVA & 0.002 & $\mathrm{NS}$ & & 0.0001 & 0.0001 \\
$100\left(\mathrm{mg} \cdot \mathrm{L}^{-1}\right)$ & & & & & \\
$4: 1: 2$ & $36.3^{*}$ & $2.8^{* *}$ & $5: 1: 2$ & $25.9^{*}$ & $2.5^{*}$ \\
$8: 1: 2$ & $41.1^{* *}$ & $3.1^{*}$ & 100 & $41.1^{* *}$ & $3.1^{* *}$ \\
$12: 1: 2$ & $35.1^{*}$ & $3.4^{*}$ & 200 & $53.9^{* * *}$ & $3.9^{* * *}$ \\
ANOVA & 0.008 & 0.006 & & 0.0001 & 0.0001 \\
$200\left(\mathrm{mg} \cdot \mathrm{L}^{-1}\right)$ & & & $12: 1: 2$ & & \\
$4: 1: 2$ & $57.5^{*}$ & $3.9^{*}$ & 50 & $27.1^{*}$ & $2.5^{*}$ \\
$8: 1: 2$ & $53.9^{*}$ & $3.9^{*}$ & 100 & $35.1^{* *}$ & $3.4^{* *}$ \\
$12: 1: 2$ & $48.5^{* *}$ & $4.4^{* *}$ & 200 & $48.5^{* * *}$ & $4.4^{* * *}$ \\
ANOVA & 0.02 & 0.01 & & 0.0001 & 0.0001 \\
\hline
\end{tabular}

${ }^{\mathrm{z}}$ Significant nutrient ratio $\times \mathrm{N}$ concentration.

${ }^{y}$ Data are means of six observations. Means followed by a different number of asterisks within a column are significantly different from each other based on single df linear contrasts.

${ }^{\mathrm{x}}$ Analysis of variance. Ns (non-significant) at $P \leq 0.05$. $P$ value given otherwise.

$\mathrm{N}=$ nitrogen; $\mathrm{P}=$ phosphorus; $\mathrm{K}=$ potassium. 
total dry weight of hibiscus was greatest when grown with $8: 1: 2$ or $12: 1: 2$, whereas total dry weight produced with $100 \mathrm{mg} \cdot \mathrm{L}^{-1} \mathrm{~N}$ was greatest with $8: 1: 2$. When produced with 200 $\mathrm{mg} \cdot \mathrm{L}^{-1} \mathrm{~N}$, total dry weight was greatest with $4: 1: 2$ and $8: 1: 2$. Thus, at all three $\mathrm{N}$ concentrations, an 8:1:2 N:P:K ratio maximized growth. These data reinforce the hypothesis proposed by Harvey et al. (2004) and Soundy et al. (2001) that plant responses should be evaluated under a range of $\mathrm{N}$ concentrations.

The $\mathrm{N}$ concentration $\times \mathrm{N}: \mathrm{P}: \mathrm{K}$ ratio interaction was significant for foliar $\mathrm{N}$ concentration of hibiscus (Table 3) but was nonsignificant for foliar $\mathrm{P}, \mathrm{K}, \mathrm{Ca}, \mathrm{Mg}$, and $\mathrm{S}$ concentrations (data not presented). At $50 \mathrm{mg} \cdot \mathrm{L}^{-1} \mathrm{~N}$, foliar $\mathrm{N}$ concentration was unaffected by $\mathrm{N}: \mathrm{P}: \mathrm{K}$ ratio, whereas at $100 \mathrm{mg} \cdot \mathrm{L}^{-1} \mathrm{~N}$, foliar $\mathrm{N}$ concentration was greatest with $8: 1: 2$ and 12:1:2 and at $200 \mathrm{mg} \cdot \mathrm{L}^{-1}, \mathrm{~N}$ foliar $\mathrm{N}$ was greatest with 12:1:2 (Table 3 ). In contrast, within each N:P:K ratio, foliar $\mathrm{N}$ concentration increased as $\mathrm{N}$ concentration increased to $200 \mathrm{mg} \cdot \mathrm{L}^{-1}$.

Foliar P concentration was unaffected by $\mathrm{N}$ concentration, whereas foliar P concentration decreased as the N:P:K ratio increased from $4: 1: 2$ to $8: 1: 2$ (Table 4). As growth was maximized at a ratio of $8: 1: 2$, the elevated foliar P concentration at 4:1:2 may be indicating luxury consumption. As $\mathrm{N}$ concentration increased in the nutrient solution, foliar $\mathrm{K}, \mathrm{Ca}$, and $\mathrm{Mg}$ concentrations decreased most likely as a result of a dilution effect because plants were also larger with higher $\mathrm{N}$ concentrations. Similarly, Dubois et al. (2000) working with Anemone xhybrida Paxton 'Margarete' (fall blooming anemone) reported foliar concentrations of $\mathrm{K}$ decreased linearly with increasing $\mathrm{N}$ concentration; however, in contrast to data here, foliar $\mathrm{P}$ increased to a plateau at 150 $\mathrm{mg} \cdot \mathrm{L}^{-1} \mathrm{~N}$ in the fertilizer solution. Wright and Niemiera (1985) reported that 'Helleri' holly required higher $\mathrm{N}$ when $\mathrm{P}$ concentration in the fertilizer solution was greater than $40 \mathrm{mg} \cdot \mathrm{L}^{-1}$. In our N:P study (2005), hibiscus grew best with $50 \mathrm{mg} \cdot \mathrm{L}^{-1} \mathrm{P}$ and a $2: 1 \mathrm{~N}: \mathrm{P}$ ratio.

Table 4. Effect of $\mathrm{N}$ concentration and N:P:K ratio on foliar mineral nutrient concentration of 'Luna Red' hibiscus (2007). ${ }^{\mathrm{z}}$

\begin{tabular}{lccccc}
\hline $\begin{array}{l}\mathrm{N} \text { concn } \\
\left(\mathrm{mg} \cdot \mathrm{L}^{-1}\right)\end{array}$ & $\begin{array}{c}\mathrm{P} \\
(\%)\end{array}$ & $\begin{array}{c}\mathrm{K} \\
(\%)\end{array}$ & $\begin{array}{c}\mathrm{Ca} \\
(\%)\end{array}$ & $\begin{array}{c}\mathrm{Mg} \\
(\%)\end{array}$ & $\begin{array}{c}\mathrm{S} \\
(\%)\end{array}$ \\
\hline 50 & 0.3 & $1.4^{* y}$ & $1.8^{*}$ & $0.9^{*}$ & $0.3^{*}$ \\
100 & 0.3 & $1.2^{* *}$ & $1.6^{* *}$ & $0.8^{*}$ & $0.2^{* *}$ \\
200 & 0.3 & $1.0^{* *}$ & $1.4^{* * *}$ & $0.7^{* *}$ & $0.3^{*}$ \\
ANOVA $^{\mathrm{x}}$ & $\mathrm{NS}$ & 0.0001 & 0.0001 & 0.0001 & 0.003 \\
$\mathrm{~N}: \mathrm{P}: \mathrm{K}$ ratio & & & & & \\
\hline $4: 1: 2$ & $0.4^{*}$ & $1.4^{*}$ & 1.7 & 0.8 & $0.29^{*}$ \\
$8: 1: 2$ & $0.2^{* *}$ & $1.1^{* *}$ & 1.6 & 0.8 & $0.25^{* *}$ \\
$12: 1: 2$ & $0.2^{* *}$ & $1.1^{* *}$ & 1.6 & 0.8 & $0.25^{* *}$ \\
ANOVA $^{\mathrm{x}}$ & 0.0001 & 0.0009 & $\mathrm{NS}$ & $\mathrm{NS}$ & 0.002 \\
\hline
\end{tabular}

${ }^{\mathrm{z}_{\mathrm{NS}}}$ nutrient ratio $\times \mathrm{N}$ concentration.

${ }^{y}$ Data are means of 12 observations. Means followed by a different number of asterisks within a column are significantly different from each other based on single df linear contrasts.

${ }^{\mathrm{x}}$ Analysis of variance. NS (non-significant) at $P \leq$ 0.05. $P$ value given otherwise.

$\mathrm{N}=$ nitrogen $; \mathrm{P}=$ phosphorus; $\mathrm{K}=$ potassium $; \mathrm{Ca}=$ calcium; $\mathrm{Mg}=$ magnesium; $\mathrm{S}=$ sulfur.
Similar to foliar P concentration, foliar concentrations of $\mathrm{K}$ were significantly higher when grown with the 4:1:2 ratio compared with $8: 1: 2$ and 12:1:2. Because plants were largest with $200 \mathrm{mg} \cdot \mathrm{L}^{-1} \mathrm{~N}$ and the $8: 1: 2$ ratio, the higher foliar $\mathrm{P}$ and $\mathrm{K}$ with the $4: 1: 2$ ratio could be luxury consumption. Additionally, $200 \mathrm{mg} \cdot \mathrm{L}^{-1} \mathrm{~N}$ and 12:1:2 did not result in greater foliar $\mathrm{P}$ or $\mathrm{K}$ even with higher $\mathrm{P}$ (16.7 $\left.\mathrm{mg} \cdot \mathrm{L}^{-1} \mathrm{P}\right)$ and $\mathrm{K}\left(33.3 \mathrm{mg} \cdot \mathrm{L}^{-1} \mathrm{~K}\right)$ in the fertilizer solution.

In contrast to hibiscus, the $\mathrm{N}$ concentration $\times \mathrm{N}: \mathrm{P}: \mathrm{K}$ ratio interaction was nonsignificant for all measured parameters of rudbeckia (data not presented). Total dry weight of rudbeckia increased from 50 to $200 \mathrm{mg} \cdot \mathrm{L}^{-1} \mathrm{~N}$, whereas total dry weight was unaffected by $\mathrm{N}: \mathrm{P}: \mathrm{K}$ (Table 5) indicating $\mathrm{P}$ and $\mathrm{K}$ were probably not limiting growth even at a ratio of 12:1:2.

Foliar $\mathrm{N}$ and $\mathrm{P}$ concentrations of rudbeckia increased as $\mathrm{N}$ concentration increased, whereas foliar $\mathrm{Ca}$ and $\mathrm{Mg}$ concentration decreased as $\mathrm{N}$ concentration increased from 100 to $200 \mathrm{mg} \cdot \mathrm{L}^{-1}$ (Table 6). Foliar $\mathrm{K}$ and $\mathrm{S}$ were unaffected by $\mathrm{N}$ concentration. Nutrient ratio affected foliar $\mathrm{P}$ and $\mathrm{K}$ concentration, which decreased as $\mathrm{N}: \mathrm{P}: \mathrm{K}$ ratio increased from 4:1:2 to $8: 1: 2$ most likely as a result of decreasing concentration in the fertilizer solution. Rudbeckia responded similarly to hibiscus in that larger plants with higher foliar $\mathrm{N}$ were grown with higher $\mathrm{N}$ concentrations $\left(200 \mathrm{mg} \cdot \mathrm{L}^{-1}\right)$; however, foliar $\mathrm{P}$ in hibiscus and $\mathrm{K}$ in rudbeckia were unaffected by $\mathrm{N}$ concentration, whereas foliar $\mathrm{P}$ in rudbeckia

Table 5. Effect of $\mathrm{N}$ concentration and $\mathrm{N}: \mathrm{P}: \mathrm{K}$ ratio on total dry weight of 'Goldstrum' rudbeckia (2007). ${ }^{\mathrm{z}}$

\begin{tabular}{lccc}
\hline $\begin{array}{l}\mathrm{N} \text { concn } \\
\left(\mathrm{mg} \cdot \mathrm{L}^{-1}\right)\end{array}$ & $\begin{array}{c}\text { Total dry } \\
\text { wt }(\mathrm{g})\end{array}$ & $\begin{array}{c}\text { N:P:K } \\
\text { ratio }\end{array}$ & $\begin{array}{c}\text { Total dry } \\
\text { wt }(\mathrm{g})\end{array}$ \\
\hline 50 & $25.3^{* \mathrm{y}}$ & $4: 1: 2$ & 33.3 \\
100 & $34.2^{* *}$ & $8: 1: 2$ & 34.2 \\
200 & $42.5^{* * *}$ & $12: 1: 2$ & 34.4 \\
ANOVA $^{\mathrm{x}}$ & 0.0001 & & $\mathrm{NS}$ \\
\hline
\end{tabular}

${ }^{\mathrm{z}} \mathrm{NS}$ nutrient ratio $\times \mathrm{N}$ concentration.

y Data are means of 12 observations. Means followed by a different number of asterisks within a column are significantly different from each other based on single df linear contrasts.

${ }^{x}$ Analysis of variance. Ns (non-significant) at $P \leq$ 0.05 . $P$ value given otherwise.

$\mathrm{N}=$ nitrogen; $\mathrm{P}=$ phosphorus; $\mathrm{K}=$ potassium.

Table 6. Effect of N concentration and N:P:K ratio on foliar mineral nutrient concentration of 'Goldsturm' rudbeckia (2007). ${ }^{\mathrm{z}}$

\begin{tabular}{lcllllc}
\hline $\mathrm{N}$ concn $\left(\mathrm{mg} \cdot \mathrm{L}^{-1}\right)$ & $\mathrm{N}(\%)$ & $\mathrm{P}(\%)$ & $\mathrm{K}(\%)$ & $\mathrm{Ca}(\%)$ & $\mathrm{Mg}(\%)$ & $\mathrm{S}(\%)$ \\
\hline 50 & $2.29^{* \mathrm{y}}$ & $0.20^{*}$ & 1.66 & $2.35^{*}$ & $0.84^{*}$ & 0.54 \\
100 & $2.93^{* *}$ & $0.23^{*}$ & 1.57 & $2.19 *$ & $0.85^{*}$ & 0.53 \\
200 & $4.09^{* * *}$ & $0.30^{* *}$ & 1.65 & $1.87^{* *}$ & $0.75^{* *}$ & 0.62 \\
ANOVA $^{\mathrm{x}}$ & 0.0001 & 0.0001 & $\mathrm{NS}$ & 0.0001 & 0.007 & $\mathrm{NS}$ \\
$\mathrm{N}: \mathrm{P}: \mathrm{K}$ ratio & & & & & & \\
\hline $4: 1: 2$ & 2.97 & $0.29^{*}$ & $1.98^{*}$ & 2.07 & 0.77 & $0.67^{*}$ \\
$8: 1: 2$ & 3.17 & $0.23^{* *}$ & $1.43^{* *}$ & 2.23 & 0.83 & $0.55^{* *}$ \\
$12: 1: 2$ & 3.18 & $0.21^{* *}$ & $1.46^{* *}$ & 2.11 & 0.84 & $0.47^{* * *}$ \\
ANOVA & $\mathrm{NS}$ & 0.002 & 0.0001 & $\mathrm{NS}$ & $\mathrm{NS}$ & 0.0001 \\
\hline
\end{tabular}

$\mathrm{z}_{\mathrm{NS}}$ nutrient ratio $\times \mathrm{N}$ concentration.

${ }^{y}$ Data are means of 12 observations. Means followed by a different number of asterisks within a column are significantly different from each other based on single df linear contrasts.

${ }^{x}$ Analysis of variance. Ns (non-significant) at $P \leq 0.05 . P$ value given otherwise.

$\mathrm{N}=$ nitrogen; $\mathrm{P}=$ phosphorus; $\mathrm{K}=$ potassium; $\mathrm{Ca}=$ calcium; $\mathrm{Mg}=$ magnesium; $\mathrm{S}=$ sulfur. 
$\mathrm{N}: \mathrm{P}\left(6.3 \mathrm{mg} \cdot \mathrm{L}^{-1} \mathrm{P}\right)$ were best for growing hibiscus, whereas higher $\mathrm{K}$ concentrations (1:2 $\mathrm{N}: \mathrm{K}, 200 \mathrm{mg} \cdot \mathrm{L}^{-1} \mathrm{~K}$ ) and lower $\mathrm{P}$ concentrations $\left(32: 1 \mathrm{~N}: \mathrm{P}, 3.1 \mathrm{mg} \cdot \mathrm{L}^{-1} \mathrm{~N}\right)$ were required for growth of rudbeckia. However, when holding $\mathrm{N}$ constant at $100 \mathrm{mg} \cdot \mathrm{L}^{-1} \mathrm{~N}$ and varying both $\mathrm{P}$ and $\mathrm{K}$ in the fertilizer solutions, higher $\mathrm{P}$ and $\mathrm{K}$ concentrations and a 2:1:2 $\left(50 \mathrm{mg} \cdot \mathrm{L}^{-1} \mathrm{P}, 100 \mathrm{mg} \cdot \mathrm{L}^{-1}\right.$ ) N:P:K ratio best supported hibiscus growth, whereas 3:1:2 (33 $\left.\mathrm{mg} \cdot \mathrm{L}^{-1} \mathrm{P}, 66 \mathrm{mg} \cdot \mathrm{L}^{-1} \mathrm{~K}\right) \mathrm{N}: \mathrm{P}: \mathrm{K}$ was needed for growth of rudbeckia. Finally, when both $\mathrm{N}$ concentration and N:P:K ratio were altered, optimum growth of both hibiscus and rudbeckia was achieved at lower and similar $\mathrm{P}$ and $\mathrm{K}$ concentrations $\left(25 \mathrm{mg} \cdot \mathrm{L}^{-1} \mathrm{P}\right.$ and $50 \mathrm{mg} \cdot \mathrm{L}^{-1}$ $\mathrm{K})$ and $200 \mathrm{mg} \cdot \mathrm{L}^{-1} \mathrm{~N}$. An 8:1:2 N:P:K ratio was optimum for production of both hibiscus and rudbeckia, although 12:1:2 N:P:K (200 $\mathrm{mg} \cdot \mathrm{L}^{-1} \mathrm{~N}, 17 \mathrm{mg} \cdot \mathrm{L}^{-1} \mathrm{P}, 33 \mathrm{mg} \cdot \mathrm{L}^{-1} \mathrm{~K}$ ) produced similar growth of rudbeckia. These two herbaceous perennials have $\mathrm{N}$ requirements similar to annual herbaceous plants and $\mathrm{P}$ and $\mathrm{K}$ requirements similar to woody perennial plants. Furthermore, our data indicate a higher ratio of N:P:K may be sufficient for herbaceous perennials compared with the current recommendations for annual or woody plants. Foliar concentrations of $2.2 \% \mathrm{~N}, 0.4 \% \mathrm{P}$, and $1.9 \% \mathrm{~K}$ should be sufficient for growth of hibiscus, whereas $2.4 \% \mathrm{~N}, 0.2 \% \mathrm{P}$, and $2.6 \% \mathrm{~K}$ are required to maximize growth of rudbeckia.

\section{Literature Cited}

Adam, S.A. and E.A. Sluzis. 2005. Nitrogen nutrition of ten species of native herbaceous perennial plants. Perennial Plants (Autumn):5-45.

Bailey, D.A. and P.V. Nelson. Undated. Designing a greenhouse crop production fertilization program. 9 Sept. $<$ http://www.ces.ncsu.edu/depts/ hort/floriculture/crop/crop_NPK>.

Campbell, C.R. and C.O. Plank. 1992. Sample preparation, p. 8-9. In: Plank, C.O. (ed.). Plant analysis reference procedures for the southern region of the United States. Georgia Agric. Expt. Sta., Southern Coop. Series Bull. 268.

Donohue, S.J. and D.W. Aho. 1992. Determination of $\mathrm{P}, \mathrm{K}, \mathrm{Ca}, \mathrm{Mg}, \mathrm{Mn}, \mathrm{Fe}, \mathrm{Al}, \mathrm{B}, \mathrm{Cu}$, and $\mathrm{Zn}$ in plant tissues by inductively coupled plasma (ICP) emission spectroscopy, p. 37-40. In: Plank, C.O. (ed.). Plant analysis reference procedures for the southern region of the United States. Georgia Agric. Expt. Sta., Southern Coop. Series Bull. 268.

Dubois, J.-J.B., S.L. Warren, and F.A. Blazich. 2000. Nitrogen nutrition of containerized Anemone $\times$ hybrida. J. Environ. Hort. 18:145148.

Foote, B.D. and R.W. Howell. 1964. Phosphorus tolerance and sensitivity of soybeans as related to uptake and translocation. Plant Physiol. 39: 610-613.

Harvey, M.P., G.C. Elliott, and M.H. Brand. 2004 Growth response of Hakonechloa macra (Makino) 'Aureola' to fertilizer formulation and concentration, and to dolomitic lime in the potting mix. HortScience 39:261-266.

Higaki, T., J.S. Imamura, and R.E. Paul. 1992. N, $\mathrm{P}$, and $\mathrm{K}$ concentrations and leaf tissue standards for optimum Anthurium andraeanum flower production. HortScience 27:909-912.

Hipp, B.W., B.J. Simpson, and P.S. Graff. 1988 Influence of nitrogen and phosphorus on growth and tissue $\mathrm{N}$ and $\mathrm{P}$ concentration in Salvia greggi. J. Environ. Hort. 6:59-61.

Hipp, B.W., B.J. Simpson, and P.S. Graff. 1989 Influence of phosphorus on nitrogen fertilizer requirement of Melampodium leucanthum (blackfoot daisy) grown in perlite-vermiculite medium. J. Environ. Hort. 7:83-85.

Hoagland, D.R. and D.I. Arnon. 1950. The water culture method for growing plants without soil Calif. Agr. Expt. Sta., Univ. of Calif., Berkeley Circ. 347.

Melton, R.R. and R.J. Dufault. 1991. Nitrogen, phosphorus, and potassium fertility regimes affect tomato transplant growth. HortScience 26:141-142.

Mills, H.A. and J.B. Jones, Jr. 1996. Plant analysis handbook II: A practical sampling, preparation, analysis, and interpretation guide. MicroMacro Publishing, Athens, GA.
Richard, R.J. and A.R. Rees. 1962. Effects of phosphate on the growth of barley under conditions of potassium deficiency. Indian J. Plant Physiol. 5:33-52.

Rodriguez, I.R., G.L. Miller, and L.B. McCarty. 2002. Bermudagrass establishment of high sand-content soils using various $\mathrm{N}-\mathrm{P}-\mathrm{K}$ ratios. HortScience 37:208-209.

SAS Institute, Inc. 2001. SAS/STAT user's guide: Release 8.2 ed. SAS Inst., Inc., Cary. NC.

Schnelle, M. and C.J. White. 2004. Nutritional management in nurseries, p. 6-10. In: Water quality handbook for nurseries. Okla. Coop. Ext. Serv. Div. Agr. Sci. and Natural Resources. Oklahoma State Univ., Stillwater. E-951. 10 May 2010. <http//osuextra.okstate.edu/pdrs/ e-951.pdf>.

Scoggins, H.L. 2005. Determination of optimum fertilizer concentration and corresponding substrate electrical conductivity for ten taxa of herbaceous perennials. HortScience 40:1504 1506.

Soundy, P., D.J. Cantliffe, G.J. Hochmuth, and P.J. Stoffella. 2001. Nutrient requirements for lettuce transplants using a floatation irrigation system II. Potassium. HortScience 36:1071-1074.

Whipker, B.E. and P.A. Hammer. 1994. Determination of injurious phosphate levels in poinsettias. HortScience 29:85-87.

Wright, R.D. 1986. The pour-through nutrient technique extraction procedure. HortScience 21:223-225.

Wright, R.D. and A.X. Niemiera. 1985. Influence of $\mathrm{N}, \mathrm{P}$, and $\mathrm{K}$ interactions on growth of Ilex crenata Thunb. 'Helleri'. J. Environ. Hort. 3:810.

Wright, R.D. and A.X. Niemiera. 1987. Nutrition of container-grown woody nursery crops, $p$. 76-101. In: Janick, J. (ed.). Hort reviews. Vol. 9. AVI Publishing Co., Inc., Westport, CT.

Yeager, T.H. and R.D. Wright. 1982. Phosphorus requirement of Ilex crenata Thunb. cv. Helleri grown in a pine bark medium. J. Amer. Soc. Hort. Sci. 10:558-562.

Zhang, D., R.E. Moran, and L.B. Stack. 2004 Effect of phosphorus fertilization on growth and flowering of Scaevola aemula $\mathrm{R}$. Br. 'New Wonder'. HortScience 39:1728-1731. 